\title{
Analysis of the grass pollen season in selected Polish cities in 2018
}

\author{
Katarzyna Dąbrowska-Zapart', Kazimiera Chłopek ${ }^{1}$, Dorota Myszkowska², Monika Ziemianin², \\ Krystyna Piotrowska-Weryszko ${ }^{3}$, Beata Żuraw ${ }^{3}$, Małgorzata Malkiewicz ${ }^{4}$, Małgorzata Puc ${ }^{5,6}$, Alina Stacewicz ${ }^{5,6}$, \\ Agnieszka Świdnicka-Siergiejko ${ }^{7}$, Ewa M. Świebocka ${ }^{8}$, Grzegorz Siergiejko ${ }^{8}$, Krystian Tywoniuk ${ }^{9}$, \\ Kornel Szczygielski ${ }^{10}$, Piotr Rapiejko ${ }^{10,}{ }^{11}$, Dariusz Jurkiewicz ${ }^{10}$, Ewa Kalinowska11, Zenon Siergiejk0"1, \\ Adam Rapiejko"11, 12, Agnieszka Lipiec ${ }^{13}$ \\ ${ }^{1}$ Faculty of Earth Sciences, University of Silesia, Sosnowiec, Poland \\ ${ }^{2}$ Department of Clinical and Environmental Allergology, Jagiellonian University Medical College, Cracow, Poland \\ ${ }^{3}$ Department of Botany, University of Life Sciences in Lublin, Poland \\ ${ }^{4}$ Laboratory of Paleobotany, Department of Stratigraphical Geology, Institute of Geological Sciences, \\ University of Wroclaw, Poland \\ ${ }^{5}$ Department of Botany and Natural Conservation, Faculty of Biology, University of Szczecin, Poland \\ ${ }^{6}$ Molecular Biology and Biotechnology Centre, Faculty of Biology, University of Szczecin, Poland \\ ${ }^{7}$ Department of Gastroenterology and Internal Medicine, Medical University of Bialystok \\ ${ }^{8}$ The Medical University of Bialystok Children's Clinical Hospital \\ ${ }^{9}$ Department of Otolaryngology, Audiology and Phoniatrics, Children's Hospital of Bydgoszcz \\ ${ }^{10}$ Department of Otolaryngology with Division of Cranio-Maxillo-Facial Surgery, Military Institute of Medicine, \\ Warsaw, Poland \\ ${ }^{11}$ Laboratory of Respiratory Diagnostics and Bronchoscopy, Medical University of Bialystok, Poland \\ ${ }^{12}$ Oxford Archaeology Ltd., Oxford, England \\ ${ }^{13}$ Department of Prevention of Environmental Hazards and Allergology, Medical University of Warsaw, Poland
}

Abstract:

The paper presents the course of the grass (Poaceae) pollen season in Bialystok, Bydgoszcz, Cracow, Sosnowiec, Lublin, Olsztyn, Szczecin, Drawsko Pomorskie, Warsaw, Piotrkow Trybunalski, Opole, Wroclaw and Zielona Gora in 2018. The pollen of grass is the primary trigger of pollen allergies during the summer months. It causes some of the most severe and difficult-to-treat symptoms. Measurements were performed by the volumetric method (Burkard and Lanzoni pollen samplers). The pollen season of Poaceae started first in Sosnowiec, Lublin and Opole in the third decade of April. The highest, record airborne concentration of 243 pollen grains $/ \mathrm{m}^{3}$ was noted in Lublin on June $19^{\text {th }}$. The maximum values of seasonal pollen count occurred between of May $27^{\text {th }}$ and June $4^{\text {th }}$ in all cities. The highest grass pollen allergen hazard occurred in 2018 in Warsaw, Lublin and Zielona Gora.

Key words: pollen concentration, allergens, grass (Poaceae), 2018

$\mathrm{n}$ various climate zones grasses are a natural component of flora. In Poland, the grass family has about 300 species [1]. Species diversity causes that the flowering period of this population is long lasting [2]. The pollination season is also long, additionally the grass pollen grain in atmospheric air can maintain for many months [3]. Grass pollen allergens are a frequent cause of periodic allergic rhinitis and conjunctivitis in many European countries [4, 5]. In Poland, they are also the main cause of pollen allergy [6]. Disease symptoms caused by grass pollen allergens appear in some patients after exceeding the concentration of 
20 grains $/ \mathrm{m}^{3}$ of air, and in all sensitized patients with exposure to concentrations above 50 grains $/ \mathrm{m}^{3}$ [7].

Aim

The aim of the study was to compare the grass pollen concentrations in the air of Bialystok, Bydgoszcz, Drawsko Pomorskie, Cracow, Lublin, Olsztyn, Opole, Piotrkow Trybunalski, Sosnowiec, Szczecin, Warsaw, Wroclaw, Zielona Gora in 2018.

\section{Material and method}

The measurments of the pollen concentration in the study sites were perfomed with the volumetric method using Burkard and Lanzoni pollen samplers. Microscopic observations were perfomed on preparations obtained in a 7-day cycle with assessment of 24-hour periods. The results were expressed as the number of pollen grians in $1 \mathrm{~m}^{3}$ of air per day $\left(\mathrm{P} / \mathrm{m}^{3}\right)$. The start of the season was defined as a date when $1 \%$ of the seasonal cumulative pollen count was trapped and the end of the season when cumulative pollen count reached $99 \%$. The total pollen count over this period was expressed by the symbol SPI (Seasonal Pollen Index). The course of the pollen seasons in each city is shown in the graphs (figs 1-6).

\section{Results and discussion}

The beginning of the pollination season in 2018 for grasses was registered in the third decade of April. The earliest in Wroclaw on April $25^{\text {th }}$, two days later in Zielona Gora, April $28^{\text {th }}$ in Sosnowiec and Opole, and in Lublin on April $30^{\text {th }}$ (figs 1-6). In the remaining measuring points, the beginning of the season was recorded in the first decade of May, and finally in Drawsko Pomorskie on May 23 $3^{\text {th }}$ (tab. 1). In 2018, the start of the pollen season was observed about two weeks earlier than in 2016-2017 [9, 10]. The end of the pollen season was registered in the second half of Sep-

Table 1. Characteristics of grass (Poaceae) pollen season in 2018.

\begin{tabular}{|c|c|c|c|c|c|c|}
\hline Site & $\begin{array}{l}\text { Duration of pollen } \\
\text { season (number and } \\
\text { days) }\end{array}$ & $\begin{array}{l}\text { Peak value } \\
{\left[\mathrm{P} / \mathrm{m}^{3}\right] \text { and }} \\
\text { peak date }\end{array}$ & $\begin{array}{l}\text { Annual } \\
\text { pollen sum }\end{array}$ & $\begin{array}{l}\text { Number of days concen- } \\
\text { tration above threshold } \\
\qquad 20 \mathrm{P} / \mathrm{m}^{3}\end{array}$ & $\begin{array}{l}\text { Number of days concen- } \\
\text { tration above threshold } \\
50 \mathrm{P} / \mathrm{m}^{3}\end{array}$ & $\begin{array}{l}\text { Number of days concen- } \\
\text { tration above threshold } \\
120 \mathrm{P} / \mathrm{m}^{3}\end{array}$ \\
\hline Bialystok & $\begin{array}{c}11.05-12.09 \\
125\end{array}$ & $\begin{array}{c}70 \\
4.06\end{array}$ & 1593 & 31 & 20 & 0 \\
\hline Bydgoszcz & $\begin{array}{c}7.05-20.09 \\
137\end{array}$ & $\begin{array}{c}154 \\
30.05\end{array}$ & 3049 & 46 & 20 & 2 \\
\hline Cracow & $\begin{array}{c}3.05-25.08 \\
115\end{array}$ & $\begin{array}{c}149 \\
20.06\end{array}$ & 2723 & 39 & 17 & 4 \\
\hline $\begin{array}{l}\text { Drawsko } \\
\text { Pomorskie }\end{array}$ & $\begin{array}{c}23.05-30.09 \\
131\end{array}$ & $\begin{array}{l}121 \\
1.06\end{array}$ & 2745 & 46 & 19 & 1 \\
\hline Sosnowiec & $\begin{array}{c}28.04-12.09 \\
138\end{array}$ & $\begin{array}{c}125 \\
19.06\end{array}$ & 2936 & 49 & 16 & 1 \\
\hline Lublin & $\begin{array}{c}29.04-24.09 \\
118\end{array}$ & $\begin{array}{c}243 \\
19.06\end{array}$ & 4973 & 49 & 37 & 12 \\
\hline Olsztyn & $\begin{array}{c}2.05-16.09 \\
138\end{array}$ & $\begin{array}{l}125 \\
1.06\end{array}$ & 3408 & 50 & 24 & 2 \\
\hline Opole & $\begin{array}{c}28.04-23.09 \\
148\end{array}$ & $\begin{array}{c}142 \\
29.05\end{array}$ & 3549 & 53 & 25 & 2 \\
\hline $\begin{array}{l}\text { Piotrkow } \\
\text { Trybunalski }\end{array}$ & $\begin{array}{c}1.05-11.09 \\
134\end{array}$ & $\begin{array}{c}146 \\
29.05\end{array}$ & 3807 & 50 & 27 & 3 \\
\hline Szczecin & $\begin{array}{c}13.05-17.09 \\
128\end{array}$ & $\begin{array}{c}177 \\
29.05\end{array}$ & 2802 & 43 & 18 & 2 \\
\hline Warsaw & $\begin{array}{c}2.05-11.09 \\
133\end{array}$ & $\begin{array}{c}158 \\
27.05\end{array}$ & 4025 & 54 & 34 & 5 \\
\hline Wroclaw & $\begin{array}{c}25.04-8.08 \\
106\end{array}$ & $\begin{array}{c}189 \\
28.05\end{array}$ & 3392 & 52 & 23 & 3 \\
\hline $\begin{array}{l}\text { Zielona } \\
\text { Gora }\end{array}$ & $\begin{array}{c}27.04-19.09 \\
146\end{array}$ & $\begin{array}{c}147 \\
28.05\end{array}$ & 4086 & 63 & 30 & 3 \\
\hline
\end{tabular}


Figure 1. Grass pollen count in Bialystok and Bydgoszcz in 2018.

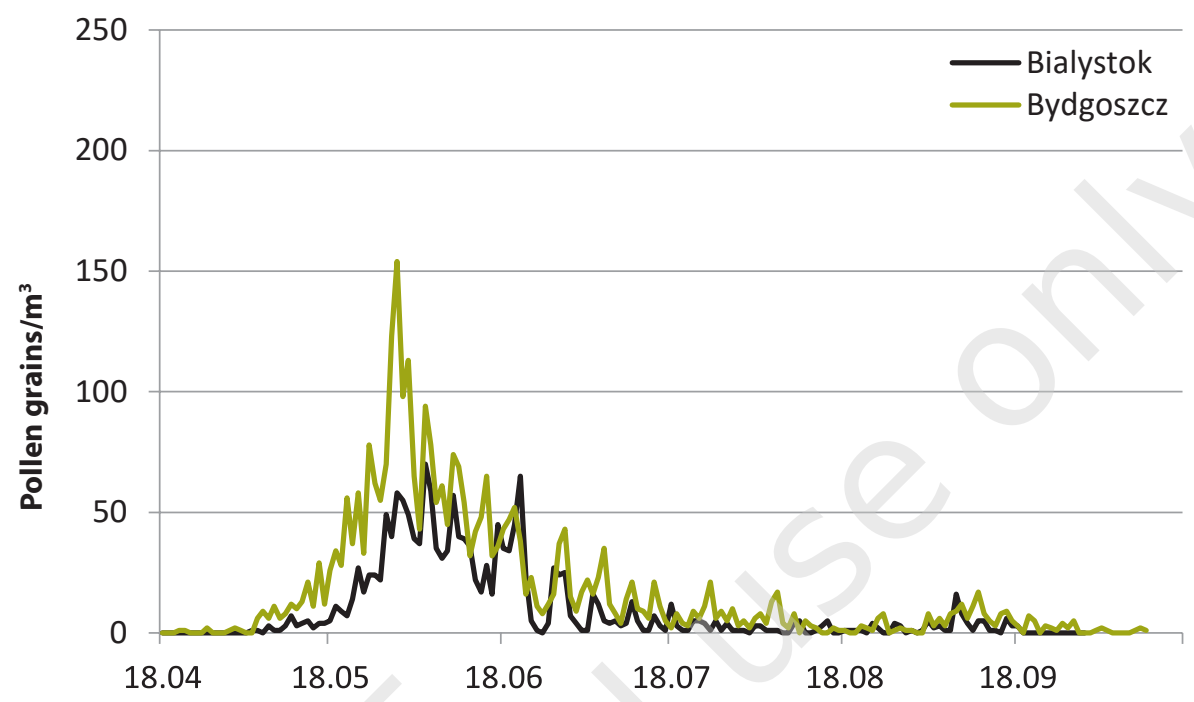

Figure 2. Grass pollen count in Cracow and Sosnowiec in 2018.

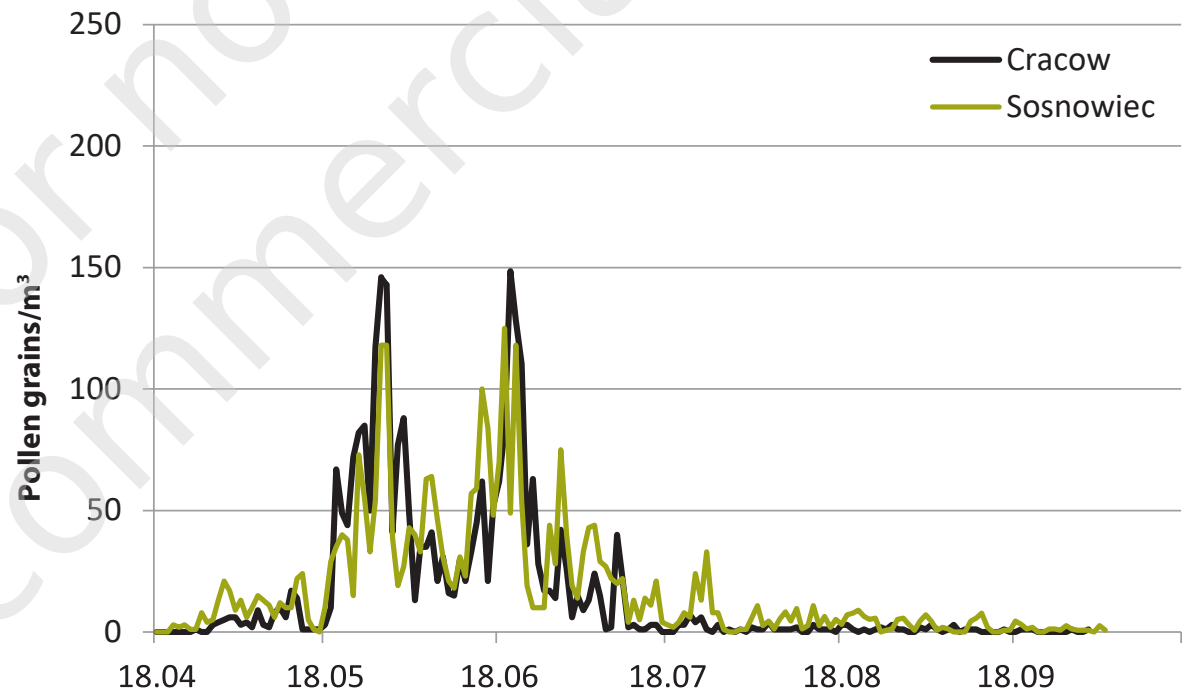

Figure 3. Grass pollen count in Lublin and Olsztyn in 2018.

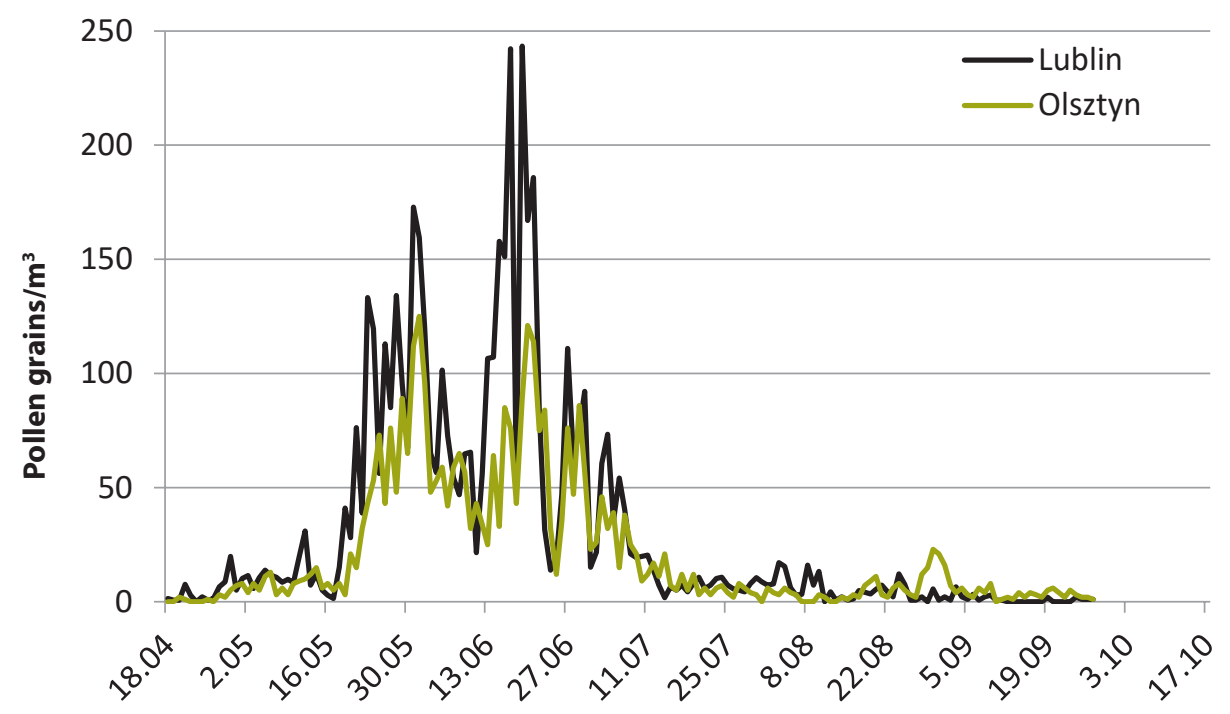




\section{MEDIGAL AEROBIOLOGY}

\section{ORIGLAL PAPER}

Figure 4. Grass pollen count in Szczecin and Drawsko Pomorskie in 2018.

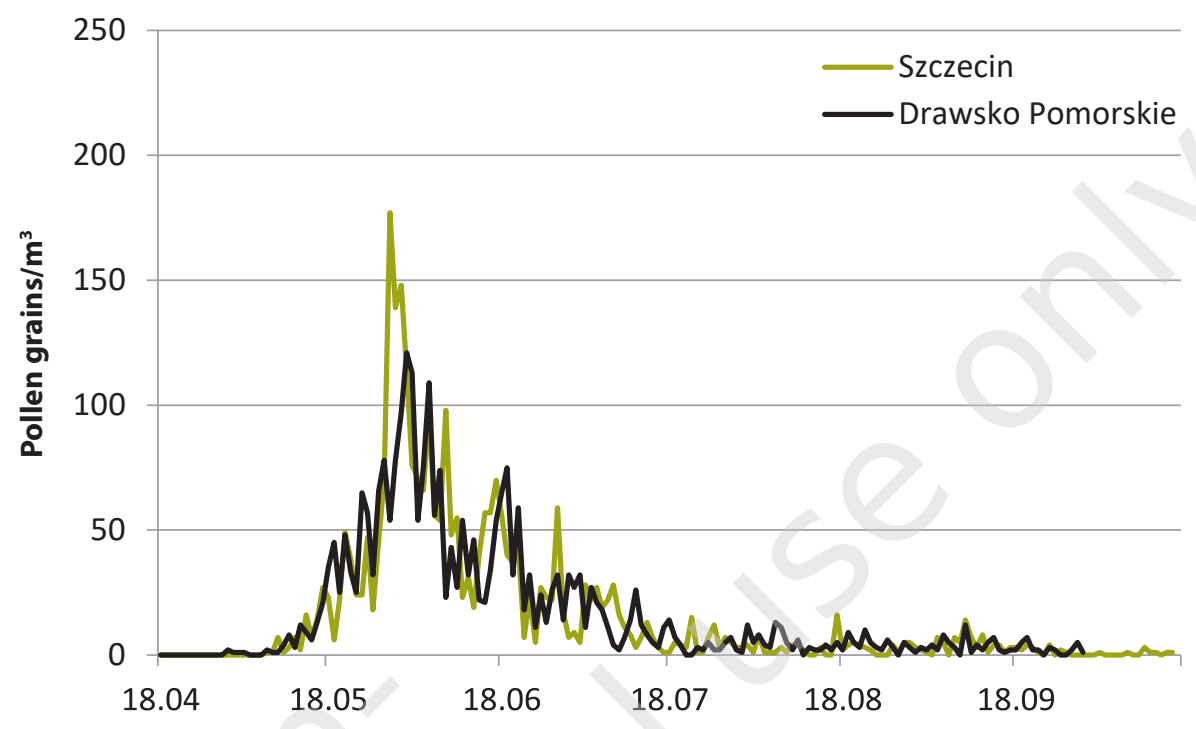

Figure 5. Grass pollen count in Warsaw and Piotrkow Trybunalski in 2018.

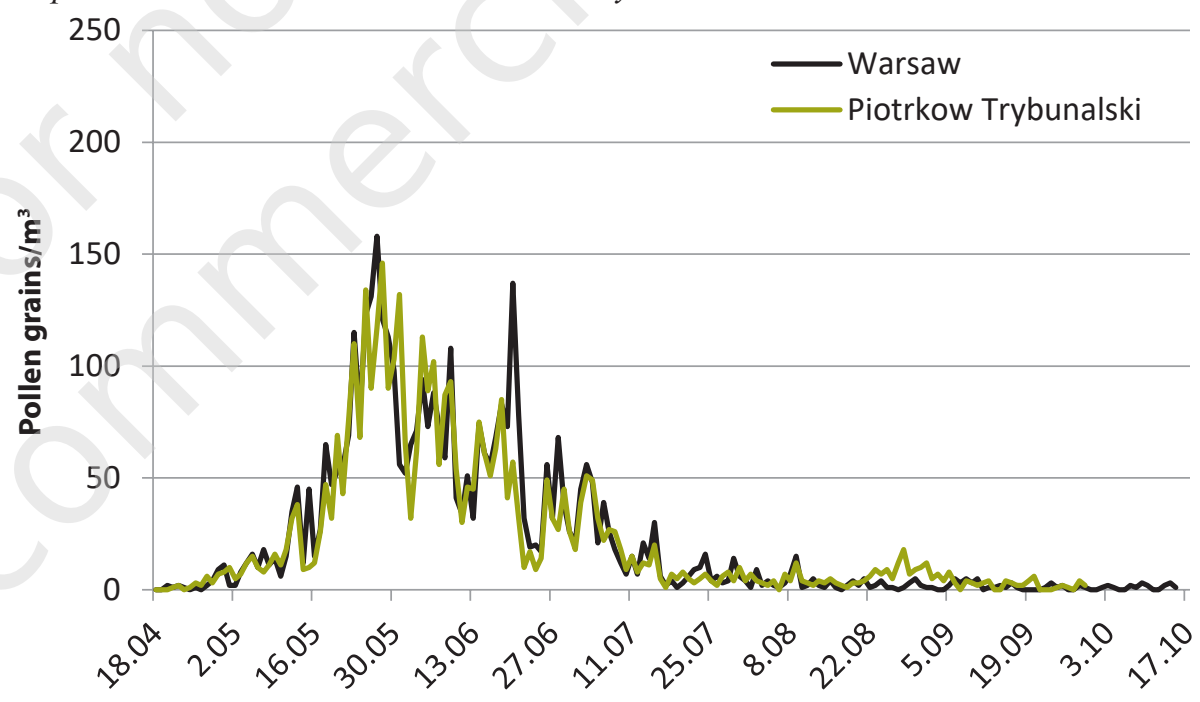

Figure 6. Grass pollen count in Opole, Wroclaw and Zielona Gora in 2018.

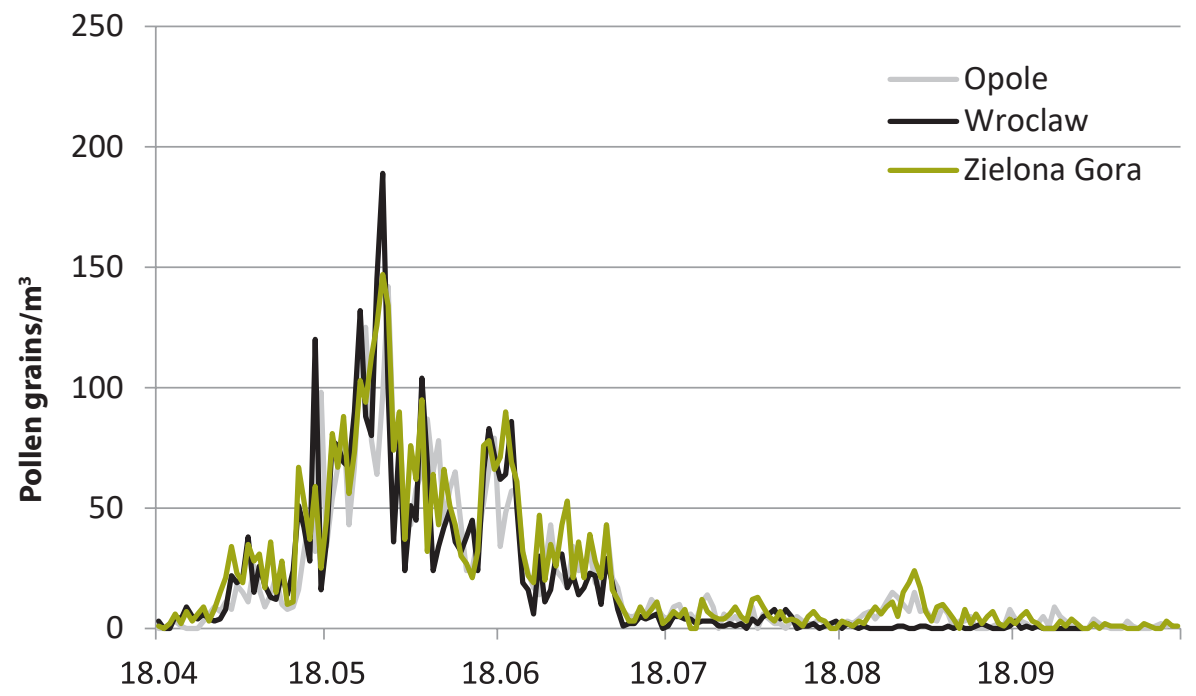


tember. The grass pollination season ended in Wroclaw exceptionally early - August $8^{\text {th }}$ and Cracow - August $25^{\text {th }}$. The longest grass pollination season was recorded in Opole (148 days) and in Zielona Gora (146 days), and the shortest in Wroclaw (106 days). In the remaining measuring points, grass pollen in the air maintained from 115 to 138 days. The pollen season of grasses in 2018 was long, but compared to the average of long-term research in the discussed cities, it did not show any significant differences [3, 8-10].

The highest values of maximum pollen grain concentration in 2018 were recorded in Lublin, amounting to $243 \mathrm{P} / \mathrm{m}^{3}$, and the lowest in Bialystok $-70 \mathrm{P} / \mathrm{m}^{3}$ (figs $1,3)$. The pollen season of grasses in the following cities was dense. The period for the occurrence of maximum concentrations of grass pollen in most of the discussed cities were registered between May $27^{\text {th }}$ and June $4^{\text {th }}$, only in Sosnowiec and Lublin the peak season occurred on June $19^{\text {th }}$, in Cracow the day after (tab. 1, figs 2, 3).

The daily concentrations of grass pollen varied between 1593 in Bialystok and 4025 in Warsaw and 4973 in Lublin. The Polish average obtained from the results was 3321. The closest to the year's annual totals were recorded in Bydgoszcz, Olsztyn, Opole, Wroclaw and Piotrkow Trybunalski (tab. 1).

The worsening of clinical symptoms in people allergic to grass pollen usually occurs after reaching a concentration of $20 \mathrm{P} / \mathrm{m}^{3}$. The number of days with such concentration ranged from 31 in Bialystok to 63 in Zielona Gora (tab. 1). Significant exposure to grass pollen allergens is demonstrated by the number of days with concentrations exceeding $50 \mathrm{P} / \mathrm{m}^{3}$ [4]. Days with such concentration were found most in Lublin (36 days) and Warsaw (34 days). A very high concentration occurred in all measuring points $\left(120 \mathrm{P} / \mathrm{m}^{3}\right)$ except for Bialystok (figs 1-6). The highest number of days was recorded in Lublin (12), in the remaining points the number of days with high concentrations ranged from 1 to 5 (tab. 1).

\section{Conclusions}

The grass pollination season in 2018 in the discussed cities started in the third decade of April and lasted until the second decade of September.

The highest daily pollen grain concentration was recorded on June $19^{\text {th }}$ in Lublin $\left(243 \mathrm{P} / \mathrm{m}^{3}\right)$.

The highest annual sum of daily concentrations of pollen grains was recorded in Lublin (4973), the lowest in Bialystok (1593).

The greatest risk of grass pollen occurrence in 2018 was in Lublin, Warsaw and Zielona Gora.

\section{References}

1. Frey L. Taksonomia traw. In: Frey L (ed). Księga polskich traw. Instytut Botaniki im. W. Szafera, Polska Akademia Nauk, Kraków 2007: 39-76.

2. Szafer W, Kulczyński S, Pawłowski B. Rośliny polskie. Wyd. IV. Państwowe Wydawnictwo Naukowe, Warszawa 1976.

3. Weryszko-Chmielewska E (ed). Pyłek roślin w aeroplanktonie różnych regionów Polski. Copyright Katedra i Zaktad Farmakognozji Wydziału Farmaceutycznego Akademii Medycznej, Lublin 2006.

4. Spieksma FThM. Airborne pollen concentrations in the European Economic Community (EEC).VI. Poaceae (Grasses) 1982-1986. Aerobiologia 1989, 5: 38-43.

5. Berger WE. Overview of allergic rhinitis. Ann Allergy Asthma Immunol 2003, 3: 7-12.

6. Ligęziński A, Rapiejko P. Koncentracja pyłku roślin w atmosferze Polski. Pnemonol Alergol Pol 1994, 62: 347-351.

7. Rapiejko P, Stankiewicz W, Szczygielski K et al. Progowe stężenia pytku roślin niezbędne do wywołania objawów alergicznych. Otolaryngologia Pol 2007, 61(4): 591-594.

8. Weryszko-Chmielewska E, Piotrowska-Weryszko K, Rapiejko P et al. Analiza sezonu pytkowego traw w 2013 roku w wybranych miastach Polski. Alergoprofil 2013, 9(3): 18-23.

9. Puc M, Kotrych D, Rapiejko P et al. The analysis of grass pollen season in northern Poland in 2016. Alergoprofil 2016, 12(4): 186-189.

10. Rapiejko P, Lipiec A, Puc M et al. The analysis of grass pollen season in northern Poland in 2017. Alergoprofil 2017, 13(4): 154-156. DOI: 10.24292/01.AP.151217.

ORCID

K. Dabrowska-Zapart - ID - orcid.org/ 0000-0002-8976-7739

D. Myszkowska - ID - orcid.org/ 0000-0002-1493-3990

M. Ziemianin - ID - orcid.org/ 0000-0003-4568-8710

K. Piotrowska-Weryszko - ID - orcid.org/ 0000-0003-3827-3218

M. Puc - ID - orcid.org/0000-0001-6734-9352

K. Szczygielski - ID - orcid.org/ 0000-0002-3717-5424

P. Rapiejko - ID - orcid.org/ 0000-0003-3868-0294

E. Kalinowska - ID - orcid.org/ 0000-0003-4821-6882

A. Lipiec - ID - orcid.org/0000-0003-3037-2326

Author's contributions:

Dąbrowska-Zapart K: $15 \%$; and other Authors: 4.47\% each

Conflict of interests: The authors declare that they have no competing interests.

Financial support: Does not occur.

Ethics: The contents presented in this paper are compatible with the rules the Declaration of Helsinki, EU directives and standardized requirements for medical journals. Research in Bialystok, Bydgoszcz, Drawsko Pomorskie, Olsztyn, Opole, Piotrkow Trybunalski, Warsaw and Zielona Gora funded by Allergen Research Center Ltd.

Corresponding author:

\section{Katarzyna Dąbrowska-Zapart, PhD}

Faculty of Earth Sciences, University of Silesia 41-200 Sosnowiec, Będzińska 60

tel.: (032) 368-94-77

e-mail: katarzyna.dabrowska-zapart@us.edu.pl 